\title{
Social disclosure: What are the main explanatory factors? An empirical test in the Tunisian context
}

\author{
Driss Rahma*, Jarboui Anis \\ Department of Finance and Accounting, Higher Institute of Business Administration (ISAAS), Tunisia \\ *Corresponding author E-mail: rahma.driss@gmail.com
}

\begin{abstract}
The paper constitutes an attempt of enrichment of researches relating to the publication of corporate social information in the annual reports. It aims to clarify the explanatory factors of the social disclosure. In fact, several research studies have focused on topics relating to the social disclosure in developed countries. However, few studies have analyzed this practice in the Tunisian context. Consequently, the paper tries to identify and assess factors that may influence the decision to publish social information in the annual reports of Tunisian companies. A survey of the literature treating of the topic of social disclosure is carried out and allowing the reformulation of the hypotheses of research. On the methodology, we made recourse to the technique of content analysis of the annual reports of 23 Tunisian companies during five years (from 2007 to 2011). As for results, we find that Tunisian companies tend to publish more information concerning the category « human resources » in comparison with the other studied informational categories (environment, products and implication in the community). As for the test of hypotheses, theses relating to the political visibility, leverage, performance, and number of employees are representing the explanatory factors of the social reporting in Tunisia.
\end{abstract}

Keywords: Social Disclosure; Voluntary Disclosure; Annual Reports; Explanatory Factors; Content Analysis.

\section{Introduction}

With major environmental and contemporary social issues, a company has an obligation to be socially responsible to its stakeholders. In fact, issues such as pollution, waste, resources depletion, product quality and safety, the rights and status of workers and the power of large corporations have become the focus of increasing attention and concern (Hussainy et al., 2011). Therefore, social disclosure refers to a company's voluntary contribution to sustainable development which goes beyond legal requirements (Gamerschlag et al., 2010).

Several research studies have focused on topics relating to the social disclosure in developed countries (Hussainy et al., (2013); Zhang (2013); Fuertes et Garcia (2013); Perrigot (2012); Farouk et al., (2011); Gamerschlag et al., (2011); Lu et al., (2010)....) However, few studies have analyzed this practice in emergent contexts like the Tunisian context.

In addition, actually, previous studies related to social disclosure are characterised by three principal types of empirical research (Reverte, 2009). In first, there are 'descriptive studies' which report on the extent and nature of social disclosure with some comparisons between countries and periods. Second, we have the 'explicative studies,' which focus on the potential factors influencing levels of social reporting. Third, there are studies on the effect of the practice of social disclosure on various users with an emphasis on market reaction (Bayoud et al., 2012).

Our study is descriptive, on the one hand, because it tries to present the level of social disclosure practice in Tunisia. On the other hand, it is an explanatory study that covers the main factors explaining the level of this practice in Tunisia. Therefore, it is essential to identify and assess factors that may influence the decision of publishing such information in the annual reports of Tunisian companies.

For this purpose, through this paper, we try to answer two main research questions: What is the extent of the social disclosure in the annual reports published by the Tunisian companies? What are the main explanatory factors of the practice of social disclosure in the Tunisian context?

As for the organization of this paper, we will take the following steps: first, a literature review is developed to lead to the reformulation of our research hypotheses. Then, we present the methodological aspect of our paper. Finally, the results generated will be discussed.

\section{Literature review and hypotheses develop- ment}

Through a review of the literature, we will present the explanatory factors of the disclosure of social information and choose those that will be empirically validated in the Tunisian context. For this, it is necessary to formulate the research hypotheses of our research on the different factors explaining the decision and the level of the publication of non financial information in the annual reports of listed companies in Tunisia.

We tried to classify our research hypotheses into four categories according to the underlying theories and type of variables which will be tested on the field:

\subsection{Hypothesis related to the prospects of legitimacy}


Social and environmental disclosures in the annual report of firms can be used in a strategic manner to manage a firm's relation with the community in which it operates that would enhance its wealth (Banwarie, 2011). Or, Cooke (1992) states that large companies are subject to greater attention than public and small companies. Thus, it should be noted that if we part of the third hypothesis of the positive theory namely the hypothesis of political costs, we find that Watts and Zimmerman (1978) state that the fact that the company is a large; this will attract the attention of holders of public power for a redistribution of wealth among different social strata.

Therefore, as explained in the positive theory, the leaders will choose accounting methods tending to reduce the size of the company to minimize the weight of the political costs while complying with laws and regulations force. Accordingly, undertakings of a large accounting policies adopted are designed to reduce their accounting result published. For most researchers, the larger companies, attracting the public, will be conducted to publish much more social information (Oxibar, 2003).

Based on all the above, we choose to formulate the following research hypothesis:

H1. There is a positive relation between the degree of political visibility and the practice of social disclosure in the annual reports of companies.

\subsection{Hypotheses relating to agency relations}

Several researches have focused on the characteristics of the capital of companies and their relation with the extent of social disclosure.

Referring to the hypotheses of the agency theory, we find that in case of a wide distribution of capital, it is likely the existence of conflicts of interest between principals and their agents. In this case the principal-agent relationship will be a focus in the management of the company. Indeed, leaders can use their degree of latitude in promoting their own interests over those of shareholders. For this we note the existence of painful agency costs that may threaten the continuity and survival of the company in the market.

Therefore, shareholders will seek additional publication besides that customary financial information. Hence, in theory, the practice of voluntary social disclosure will be more intensive in the case where capital is diluted. Several authors have argued that positive relationship between the dispersion of capital and social disclosure such as Dhaliwal et al., (2011), Ben Ali and Summa (2006), Oxibar (2003), Roberts (1992) and Ullmann (1985). We therefore hypothesize the following:

H2. The degree of dilution of the company's capital has a positive impact on the practice of social disclosure in the annual reports of companies.

The leverage has long been considered as a mechanism to resolve conflicts of interest in the company.

Some authors confirm a positive relationship between the level of debt and the extent of social disclosure in the annual reports of companies. Indeed, Ullmann (1985) considers more than the company needs to borrow to finance its projects, more than the leaders will have to meet the expectations of creditors concerning compliance with the social responsibility of business.

Laan (2009) finds that environmental performance has a significant and positive association with both leverage and voluntary environmental disclosures.

Other researchers found a negative relationship between debt and the decision to disclose social information (Belkaoui and Karpik (1989), Oxibar (2003, 2009), Cormier and Magnan (1999). According to these previous studies, information related to the socia responsibility of the company does not affect the decision of donors who will provide liquidity to the company. In conclusion, for our research, we propose to test the following research hypothesis: H3. The leverage has an impact (positive or negative) on social disclosure.

\subsection{Hypotheses relating to control variables}

Some researchers argue that when the company is successful, this will encourage them to disclose voluntary information other than statutory financial information (Ayedi (2006), Freedman and Jaggi (1998), Cormier and Magnan (1999), Roberts (1992)).

However, other researchers confirmed a negative relationship between the performance of the company and its level of social disclosure.

We can explain further indicating that the social disclosure may affect negatively the competitive position of the company by showing its qualities and strengthens to its competitors. This may discourage the company to adopt a strategy of voluntary social communication. But, if the company will set as a major goal the provision of comprehensive and transparent to its current and potential investor's information, his strategy will be oriented towards maximizing publishing social information in order to keep its investors and attract new donors of funds.

On the basis of all that follows, we rephrase the following research hypothesis:

H4. The performance of the company has a positive influence on the practice of social disclosure in annual reports.

The number of employees represents a variable that must be tested empirically in order to have a complete idea about the relationship between a company and its environment and society (Zhang, 2013). Indeed, it is not satisfactory to test the size of a company or its degree of political visibility by means of financial data. This statement can be explained better in practice: there are companies that make huge turnover with only two or three employees as there are companies that make the same sales using a remarkably effective. It will be useful to test the control variable can be an added value in research in addition to the usual financial measures.

To this end, according to Cormier et al., (2006), where the company employs a large number of workers, it would have to meet their social and ensure transparency and reliability of information about the activities of its employees. This allows us to offer a positive relationship between the number established by a company and its level of social disclosure and especially those related to human resources.

Therefore, our research hypothesis will be presented as follows:

H5. There is a positive relation between the number of employees of a company and the extent of its social and environmental disclosure.

\section{Methodology}

In our study, our goal is to assess the level of social disclosure in the annual reports of companies as well as the factors explaining the adoption of this decision.

\subsection{Sample, period study and data source}

Our base sample consists on 23 Tunisian companies listed on the Stock Exchange of Tunisia. Indeed, we excluded all listed companies in the financial sector such as banks, financial institutions and insurance companies.

Our study extends over five years, namely from 2007 to 2011 . The reason for choosing this period of our research is the availability of prior information for the firms in our sample.

It should be noted that our sample is considered sample panel.

At the stage of data collection, we relied on three sources of data and we proceeded as follows:

First, we collected annual management reports prepared by the Board of Tunisian companies listed on the stock exchange in Tunisia from the Board of the Tunisian financial market. Then, we collected annual reports auditors that contain the financial statements of Tunisian companies as well as the opinion of the auditors from the site. Available at: http://www. bvmt.com.tn . Finally, we use sheets overview of Tunisian listed companies published on the 
internet to expand our knowledge of the companies belonging to our final sample.

It should be noted that the review of the annual report as a means of publication is explained by its importance and wealth on voluntary and non-financial information.

\subsection{Definition and measurement of variables}

The variables to set contain an endogenous variable (dependent variable) and a set of exogenous variables.

\subsubsection{Dependent variable: Social disclosure}

The measurement of the dependent variable in our model requires the introduction of the technique of content analysis of annual reports collected.

In this context, it is to indicate that most studies dealing with social reporting in annual reports were based on the method of content analysis of these documents. Indeed, Ernst and Ernst (1978) study focuses on the analysis of social information disclosed in the annual reports of 500 U.S. companies. Subsequently, researchers who have studied the practices of social disclosure used the same technique (Yao (2011), Hassan (2010), Suttipun (2012), Kuo (2012), Gutiérrez )2013), Guthrie and Mathews (1985), Zéghal and Ahmed (1990), Hakston and Milne (1996), Oxibar (2003, 2009)). In fact, by using the method of content analysis of annual reports, we have as an essential aim to classify the information specified in the parsed document as social information.

This requires the construction of an analytical framework of social information which we consider the frequently published in the Tunisian context. For this we present this list of items relating to the social disclosure:

Category (1): Environment

Sub- Category (1): Pollution

Item (1): Respect of standards for pollution

Item (2): Efforts made to reduce pollution

Item (3): Repair damage resulting from activity

Sub- Category (2): Recycling

Item (1): Conservation of natural resources

Item (2): Use of recycled materials

Item (3): Waste recovery

Sub- Category (3): Energy

Item (1): Optimal use of resources throughout the production process

Item (2): Waste prevention

Item (3): Reduction of energy consumption

Sub- Category (4): Other

Item (1): Contribution to the protection of nature

Item (2): Monetary donations to help the protection of environment

Category (2): Products

Sub- Category (1): Research and development

Item (1): Information related on development of products

Item (2): Costs of research and development

Item (3): Information related on improving future products

Sub- Category (2): Quality

Item (1): Information related on quality of products

Sub- Category (3): Security

Item (1): Information related on the product security

Item (2): Information indicating compliance with the safety standard

Item (3): Information on strengthening health qualities in the production process

Item (4): Information related on the products safety

Sub- Category (4): Other

Item (1): Other information related to products

Category (3): Human resources

Sub- Category (1): Information on general working conditions

Item (1): Terms of hygiene and safety

Item (2): Employee motivation

Item (3): Information on absenteeism
Item (4): Improving general working conditions

Item (5): Provide medical support to the employee

Sub- Category (2): Analysis and development of staff

Item (1): Workforce

Item (2): Distribution of employees by employment contract

Item (3): Rotation or changing employees

Sub- Category (3): Information on recruitment policies and compensation

Item (1): Reasons for change in number of employees

Item (2): Layoffs

Item (3): compensation policies

Item (4): Relationships with unions

Item (5): Staff strikes and social conflicts

Sub- Category (4): Training

Item (1): Training plan

Item (2): Number of trained employees

Item (3): Training time

Item (4): Training expenses

Sub- Category (5): Other

Item (1): Information on employee's seniority

Item (2): Information on work accidents

Item (3): Social climate and work environment

Category (4): Community involvement

Sub- Category (1): Arts

Item (1): Donations for the arts

Item (2): Sponsoring actions arts

Sub- Category (2): Education

Item (1): Donations for teaching and education

Sub- Category (3): Human health

Item (1): Donations for health

Item (2): Help to the local employment development or other local activities

Regarding the unit of measurement of societal information, we will use the number of sentences written in the annual reports of companies tested.

In addition, we have chosen to measure this variable by the number of sentences dealing with societal information in the annual report of companies of our sample. In fact, the number of sentences is the most reliable and the most relevant measure for this unit containing a coherent idea and having a clear sense that we can provide reasonable assurance that our results are not biased.

\subsubsection{Independent variables}

Table 1: Measures of independent variables

\begin{tabular}{|c|c|c|c|}
\hline $\begin{array}{l}\text { Explanatory } \\
\text { variable }\end{array}$ & Measures in the literature & Measure used & $\begin{array}{l}\text { Expected } \\
\text { sign }\end{array}$ \\
\hline \multicolumn{4}{|c|}{ Variable relating to prospects of legitimacy } \\
\hline $\begin{array}{l}\text { Political } \\
\text { visibility }\end{array}$ & $\begin{array}{l}\text { Total Assets } \\
\text { Turnover } \\
\text { Logarithm of turnover } \\
\text { Number of employees } \\
\text { Market capitalization } \\
\text { Logarithm of total Assets }\end{array}$ & $\begin{array}{l}\text { Logarithm of } \\
\text { turnover }\end{array}$ & $(+)$ \\
\hline \multicolumn{4}{|c|}{ Variables relating to agency's relations } \\
\hline $\begin{array}{l}\text { Dilution of } \\
\text { capital }\end{array}$ & $\begin{array}{l}1-\text { Percentage of capital } \\
\text { held by shareholders with } \\
5 \% \text { or more of the capital } \\
1-\Sigma(\% \mathrm{~K} \text { of inst.Invest, } \% \mathrm{~K} \\
\text { of the State, } \% \mathrm{~K} \text { of employ- } \\
\text { ees, \%K of family share- } \\
\text { holders) }\end{array}$ & $\begin{array}{l}100-\% \text { of } \\
\text { capital of the } \\
\text { largest share- } \\
\text { holder. }\end{array}$ & $(+)$ \\
\hline Leverage & $\begin{array}{l}\text { Financial debts / total assets } \\
\text { Total debts / total assets } \\
\text { Total debts / Total equity }\end{array}$ & $\begin{array}{l}\text { Ratio : Finan- } \\
\text { cial debts / total } \\
\text { assets }\end{array}$ & $(+/-)$ \\
\hline \multicolumn{4}{|c|}{ Control variables } \\
\hline Performance & $\begin{array}{l}\text { Result } \\
\text { ROE : (Result /Equity) } \\
\text { ROA : (Result /Total assets) } \\
\text { Ratio : Result /Turnover }\end{array}$ & ROE & $(+)$ \\
\hline $\begin{array}{l}\text { Number of } \\
\text { employees }\end{array}$ & Total number of employees & $\begin{array}{l}\text { Logarithm of } \\
\text { Total number } \\
\text { of employees }\end{array}$ & $(+)$ \\
\hline
\end{tabular}




\subsection{Model}

The model that will be tested in our empirical validation is the following:

$\mathrm{SD}_{\mathrm{it}}=\beta_{0}+\beta_{1}(\mathrm{PV})_{\mathrm{it}}+\beta_{2}(\mathrm{DC})_{\mathrm{it}}+\beta_{3}(\mathrm{~L})_{\mathrm{it}}+\beta_{4}(\mathrm{P})_{\mathrm{it}}+\beta_{5}(\mathrm{NE})_{\mathrm{it}}+\varepsilon_{\mathrm{it}}$

Where;

$\mathrm{SD}=$ Social Disclosure; $\mathrm{PV}=$ Political Visibility; $\mathrm{DC}=$ Dilution of Capital; L= Leverage; $\mathrm{P}=$ Performance; $\mathrm{NE}=$ Number of employees; $\varepsilon_{\mathrm{it}}=$ error term.

Our model requires the use of a series of panel data. For this, we use the indices $\mathrm{i}$ and $\mathrm{t}$ for different variables as well as the dependent variable. These indices correspond to the company and the period of the study.

$i=1,2,3, \ldots, 23 ; t=2007,2008,2009,2010,2011$.

This model focuses on panel data to exploit the temporal dimension (5 years) and the individual dimension ( 23 companies).

\section{Empirical results}

Through content analysis of annual reports, we will proceed in the first instance to the analysis of the importance of corporate social disclosure by companies from one year to another (from 2007 to 2011). Subsequently, we will try to discuss about the different factors that may influence this practice.

\subsection{Social disclosure level in the annual reports of Tuni- sian companies}

Collected data shows a clear increase in the level of disclosure of social information in the annual reports of Tunisian companies from one year to another. Indeed, the number of sentences describing the environmental and social information increased by 214 sentences between 2007 and 2011.

Table 2: Evolution of the level of social disclosure

\begin{tabular}{lclllllc}
\hline & \multicolumn{8}{c}{ Number of sentences (NS) } & \multirow{2}{*}{ (NS } & (\% \\
& 200 & 200 & 200 & 201 & 201 & ) & ) \\
& 7 & 8 & 9 & 0 & 1 & & \\
\hline Category 1: Environment & 86 & 103 & 107 & 112 & 110 & 518 & 16 \\
& 250 & 220 & 203 & 223 & 222 & 111 & 34 \\
Category 2: Products & 171 & 307 & 340 & 366 & 370 & 155 & 47 \\
$\begin{array}{l}\text { Category 3: Human } \\
\text { resources }\end{array}$ & 15 & 36 & 25 & 34 & 34 & 144 & 3 \\
$\begin{array}{l}\text { Category 4: Community in- } \\
\text { volvement }\end{array}$ & 522 & 666 & 675 & 735 & 736 & 333 & 10 \\
$\begin{array}{l}\text { Level of social disclosure by } \\
\text { year }\end{array}$ & & & & & & & 0 \\
\hline
\end{tabular}

So, all the above-presented results can be summarized in the following graph:

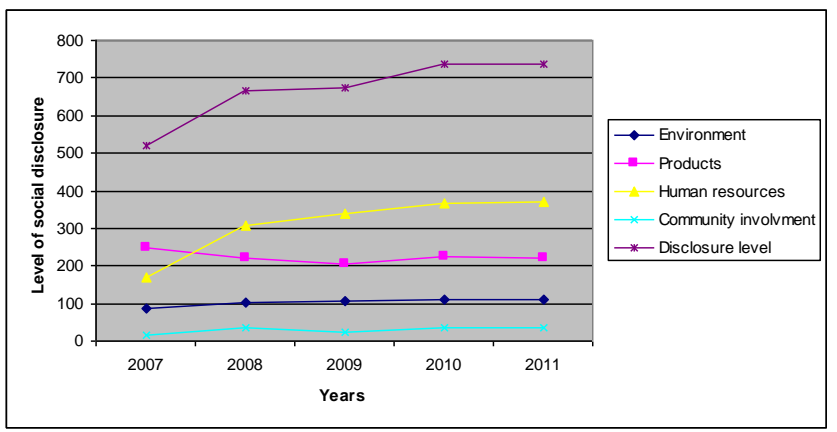

Fig. 1: Level of social disclosure based on categories of information

Looking at the graph which shows schematically the overall level of social disclosure based on category's number of sentences, we find that the total number of sentences related to social disclosure in annual reports is 3334 sentences for a period spanning five years. The number of sentences measuring the extent of voluntary disclosure of such information is made including: 1554 sentences dealing with human resources, 1118 sentences covering products, 518 sentences describing the business environment and 144 sentences relating to the level of involvement of Tunisian companies in the community. It is, therefore, noted that the number of the highest sentences is the human resources.

Therefore, during our study period, we find that social information published by Tunisian companies tend to increase from one year to another. Moreover, the social information related to human resources is present in an excessive manner in the annual reports than the other themes which are: environment, products and community involvement.

\subsection{Model estimation and results discussion}

To estimate our model, it's necessary at first to operate two principal tests.

In the one hand, we have the homogeneity test which allowed us to see that data can be treated as panel data.

Table 3: Results of the homogeneity test

\begin{tabular}{llllr}
\hline \multicolumn{1}{c}{ Variables } & \multicolumn{4}{c}{ Regression } \\
\cline { 2 - 5 } & Expected sign & Coefficient & t-stat & $\begin{array}{c}\text { P } \\
\text { value }\end{array}$ \\
\cline { 2 - 5 } Constant & $/$ & 146.3049 & 3.738282 & 0.0003 \\
LOGCA & + & -16.22671 & -3.205455 & 0.0018 \\
DILC & + & 0.237052 & 1.692159 & 0.0935 \\
ENDETT & $+/-$ & -35.97444 & -3.023813 & 0.0031 \\
ROE & + & -32.03352 & -1.835143 & 0.0692 \\
EFFECT & + & 0.003753 & 0.845738 & 0.3996 \\
R-squared & & 0.163575 & & \\
Adjusted R-squared & & 0.125207 & & \\
S.E. of regression & & 27.95647 & & \\
Sum squared resid & & 85190.50 & & \\
Log likelihood & & -543.1214 & & \\
F-statistic & & 4.263318 & & \\
Prob(F-statistic) & & 0.001403 & & \\
\hline
\end{tabular}

Where; $\mathrm{C}=$ Constant; LOGCA $=$ the political visibility measured by the Logarithme of turnover; DILC $=$ the dilution of capital (100 -\% of capital held by the largest shareholder); ENDETT $=$ the leverage determined by the ratio calculating the total Financial debts over total assets; $\mathrm{ROE}=$ the measure of performance, Result by Equity; EFFECT= the number of employees measured by the Logarithme of total number of employees.

In the other hand, we use the test of Hausman (1978) which is a test specification of individual effects. It is used to discriminate specific fixed effects and random effects. This test allowed us to choose the model of fixed effects panel data.

Table 4: Results of the test of Hausman (1978)

\begin{tabular}{|c|c|c|c|c|}
\hline \multirow[t]{2}{*}{ Variables } & \multicolumn{4}{|c|}{ Regression } \\
\hline & Expected sign & Coefficient & t-stat & $\begin{array}{c}\mathrm{P} \\
\text { value }\end{array}$ \\
\hline Constant & I & 54.53224 & 2.163500 & 0.0332 \\
\hline LOGCA & + & -1.211395 & -0.413321 & 0.6804 \\
\hline DILC & + & -0.277516 & -1.540632 & 0.1270 \\
\hline ENDETT & $+/-$ & -1.101786 & -0.135695 & 0.8924 \\
\hline ROE & + & -14.87861 & -1.263268 & 0.2099 \\
\hline EFFECT & + & $5.84 \mathrm{E}-06$ & 0.000609 & 0.9995 \\
\hline R-squared & & 0.861589 & & \\
\hline Adjusted R-squared & & 0.818634 & & \\
\hline S.E. of regression & & 12.72938 & & \\
\hline Sum squared resid & & 14097.22 & & \\
\hline Log likelihood & & -439.6840 & & \\
\hline F-statistic & & 20.05795 & & \\
\hline Prob(F-statistic) & & 0.000000 & & \\
\hline
\end{tabular}


Where $\mathrm{C}=$ Constant; LOGCA $=$ the political visibility measured by the Logarithme of turnover; DILC $=$ the dilution of capital $(100-\%$ of capita held by the largest shareholder); ENDETT $=$ the leverage determined by the ratio calculating the total Financial debts over total assets; ROE $=$ the measure of performance, Result by Equity; EFFECT = the number of employees measured by the Logarithme of total number of employees.

The final result provided by the "WINRATS" software regarding the regression using ordinary least squares model on panel data is as follows:

Table 5: Results of the test of hypotheses

\begin{tabular}{lllll}
\hline \multirow{2}{*}{ Variables } & \multicolumn{4}{c}{ Regression } \\
\cline { 2 - 5 } & Expected sign & Coefficient & t-stat & P value \\
\hline Constant & $/$ & 5.453224 & 2.163500 & 0.0332 \\
LOGCA & + & -1.211395 & -0.413321 & 0.03876 \\
DILC & + & -0.277516 & -1.540632 & -0.05533 \\
ENDETT & $+/-$ & -1.101786 & -0.135695 & -0.03600 \\
ROE & + & -14.87861 & -1.263268 & -0.01496 \\
EFFECT & + & $5.84 \mathrm{E}-06$ & 0.000609 & -0.04438 \\
\hline
\end{tabular}

Where; $\mathrm{C}=$ Constant; LOGCA $=$ the political visibility measured by the Logarithme of turnover; DILC $=$ the dilution of capital (100 -\% of capital held by the largest shareholder); ENDETT = the leverage determined by the ratio calculating the total Financial debts over total assets; $\mathrm{ROE}=$ the measure of performance, Result by Equity; EFFECT $=$ the number of employees measured by the Logarithme of total number of employees.

From the table above-presented, we note that the hypotheses that have been validated by the empirical test are the hypothesis $n^{\circ} 1,3$ 4 and 5. This implies that political visibility, leverage, performance and workforce are the factors explaining the practice of disclosure of social information in the annual reports of listed Tunisian firms. In contrast, the hypothesis $\mathrm{n}^{\circ} 2$ was not validated. So, the dilution of capital has no effect on the practice of voluntary social reporting. In what follows, we will interpret our results, hypothesis by hypothesis.

The hypothesis related to the political visibility was confirmed. This implies that political visibility has a significant effect on the decision to disclose social information by Tunisian companies. In fact, large companies are subject to a great deal of attention from the public. As part of the positive theory, these companies tend to disclose more societal information to meet expectations and pressure groups and publish transparent information (financial and non-financial).

Concerning the hypotheses related to agency relations, we have, firstly, the dilution of capital.

This hypothesis is reversed. As for the results of hypothesis testing, a negative and not significant association was found between the level of voluntary disclosure of social information and the degree of dilution of the capital of Tunisian companies.

This allows us to reject the hypothesis which states that the dilution of capital has a positive impact on the disclosure of social information in the annual reports of Tunisian companies.

In conclusion, in Tunisia, the level of dispersion or concentration of capital has no impact on the decision to publish societal information.

Second, concerning the hypothesis of leverage, it was confirmed by our empirical study. In fact, it was found that the financial structure (the use of debt or not) has a negative and highly significant impact on the level of publishing social information in annual reports.

Referring to the review of previous empirical studies, we find that some previous researchers have resulted in a positive relation between leverage and social disclosure whereas other researchers have confirmed the negative sign of this relationship disclosure.

In the Tunisian context, our results lead us to say that most companies that make use of debt they don't opt for the disclosure of social information.

This can be explained by the fact that donors do not need such additional information as they will take the decision to agree to fund a business or refuse to do. They need more financial information, its financial capacity and credit information.
Finally, we have the hypotheses about the control variables; the hypothesis related to the performance of the company was confirmed. Indeed, the performance measured by ROE (Return on equity) has been negatively correlated with the decision of social disclosure.

This means that more Tunisian firms are efficient less they are interested in publishing social information in annual reports voluntarily. So, companies with a policy of only financial profit don't tend to disclose this information.

In Tunisia, we find that the number of company's employees is negatively correlated with the decision of the voluntary disclosure of social information. This means that unless the labor force is important more the extent of social disclosure will be wide.

This result is in agreement with the results of the performance of the company where it was shown to be negatively correlated with the decision of social disclosure.

In conclusion, in our sample, successful businesses and having a significant number of employees do not opt for disclosure of environmental and social information in annual reports.

\section{Conclusion}

Our study has a double objective. On the one hand, it aims to analyze the importance of the practice of voluntary disclosure of social information and its extent in the annual reports of 23 Tunisian companies for five years from 2007 until 2011. On the other hand, it seeks to identify the factors influencing the decision and the level of disclosure of social information.

The content analysis allowed us to conclude that the total societal information published by Tunisian companies has increased between 2007 and 2011. However, we note that even with this remarkable development, the overall level is still in an early stage and not too developed and this is due to its voluntary nature and the lack of legislation requiring the disclosure of such information periodically to the public. The classification of information as proposed by our research allowed us to conclude that the Tunisian companies tend to publish more information about the "Human Resources" in first order.

Regarding hypothesis testing, it was decided to confirm the hypothesis about political visibility, leverage, performance of company and number of employees. Indeed, large companies are more concerned with social disclosure to give a holistic view of their activities and to convince the lobbies of the legitimacy of their actions. In addition, for our sample we found that more companies are opting for leverage unless they decide to communicate social information in its annual reports. Moreover, from our results, it was found that companies are very concerned only by their benefit and they don't pay attention to non-financial information. For this, performance is negatively correlated with social disclosure. As for workforce, when the number of employees of Tunisian firms increases, the level of social disclosure decreases and this is in agreement with the results related to the performance.

The hypothesis related to the dilution of capital has not been validated. Consequently, it cannot be an explanatory factor of the decision of voluntary publication of social information in the Tunisian context. Finally, our study has some limitations: firstly, the size of the selected sample is reduced. It is therefore proposed to support studies addressing the same core issue of research on larger samples. On the other hand, we can find other internal or external factors explaining the decision of disclosure of social information. We can cite the example of social factors such as social climate and culture of the company. In addition, you can look for other informational materials other than the annual report to collect more data about the companies and the strategic choice led by leaders such as websites and advertising catalogs.

\section{References}

[1] Abbott W.F. and Monsen R.J., (1979), «On the measurement of corporate social responsibility: self-reported disclosures as a method of 
measuring corporate social involvement», Academy of Management Journal, September, pp. 501-515.

[2] Bayoud N., Kavanagh M. and Slaughter G. (2012), «Factors Influencing Levels of Corporate Social Responsibility Disclosure by Libyan Firms: A Mixed Study », International Journal of Economics and Finance Vol. 4, No. 4.

[3] Belkaoui A. and Karpik G. (1989), «Determinant of the corporate decision to disclose social information», Accounting, Auditing and Accountability Journal, Vol N², pp. 26-51.

[4] Ben Yedder M. and Zaddem F. (2009), « La Responsabilité Sociale de l'Entreprise (RSE), voie de conciliation ou terrain d'affrontements? », Revue multidisciplinaire sur l'emploi, le syndicalisme et le travail, vol No4, $\mathrm{n}^{\circ} 1$, pp. 84-103.

[5] Branco M. and Rodrigues L. (2008), «Factors Influencing Social Responsibility Disclosure by Portuguese Companies», Journal of Business Ethics, pp.685-701.

[6] Cooke T., (1992), «The impact of size, stock market listing and industry type on disclosure in the annual reports of Japanese listed corporations», Accounting and Business Research, $\mathrm{Vol} \mathrm{N}^{\circ} 22$, Issue 87, pp. 229-237.

[7] Cormier D. and Magnan M. (1999), «Corporate Environmental Disclosure Strategies: Determinants, Costs and Benefits», Journal of Accounting, Auditing and Finance; $\mathrm{Vol} \mathrm{N}^{\circ} 14$, Issue 3, pp.429-451.

[8] Cormier D., Gordon I. M. and Magnan M. (2004), «Corporate Environmental Disclosure: Contrasting Management's Perceptions with Reality», Journal of Business Ethics, Vol N49, pp. 143-165.

[9] Cowen S., Ferreri L. and Parker L.D., (1987), «The impact of corporate characteristics on social responsibility disclosure: a typology and frequency based analysis», Accounting, Organizations and Society, Vol N¹2, Issue 2, pp. 111-122.

[10]Dammak Ayedi S. (2006), « Determinants of the corporate decision to disclose stakeholders' reports in France », Accounting Control Audit Review, Vol N²12/2006, pp.73-116.

[11]Dhaliwal S. , Oliver L., Tsang A. and Yang G. (2011), «Voluntary Nonfinancial Disclosure and the Cost of Equity Capital: The Initiation of Corporate Social Responsibility Reporting» The Accounting Review, Volume 86, Issue 1.

[12]Ernst et Ernst (1978), «1977 Survey of Fortune 500 Annual Reports», Ernst\&Ernst Cleveland Ohio.

[13]Freedman M. and Jaggi B. (1998), «An analysis of the association between pollution disclosure and economic performance», Accounting, Auditing and Accountability Journal, Vol N${ }^{\circ}$, Issue 2, pp.43-58.

[14]Giordano G. (2007), « Comment crédibiliser le reporting sociétal ? », Revue de Comptabilité Contrôle Audit, Vol N 13, Issue12/2007, pp. 127-143.

[15]Gray R., Owen D. and Adams C. (1996), « Accounting and accountability: changes and challenges in corporate social and environmental reporting», Prentice Hall.

[16]Guthrie J. and Mathews M.R., (1985), «Corporate social accounting in Australasia», Research in corporate social performance and policy, vol. 7, p. 251-277.

[17]Hackston D. and Milne M., (1996), «Some determinants of social and environmental disclosure in New-Zealand companies», Accounting, Auditing and Accountability Journal, vol. 9, n 1, p. 77-108.

[18]Hussainy K., Elsayed M. and Abdelrazek M. (2011) «Factors affecting corporate social responsibility disclosure in Egypt », Corporate Ownership and Control journal.

[19]Matoussi H. and Chakroun R., (2010), « Confrontation entre l'offre et la demande d'informations volontaires au niveau des rapports annuels dans un pays émergent : cas de la Tunisie », Crises et nouvelles problématiques de la Valeur, Nice, France, Vol N¹, pp.1-12.

[20]Oxibar B. (2005), « La diffusion d'information sociétale : outil de mesure et déterminants : une comparaison multi supports ». Actes du 26ème congrès de l'Association Francophone de Comptabilité.

[21]Oxibar B. and Déjean F. (2006), « Pratiques de diffusion d'information sociétale : Le cas Péchiney », Humanities and Social Sciences/Business administration.

[22]Parguel B. and Benoit F. (2007), «Communication sociétale et capitalmarque», Cahier de recherches n`362 publiée en Mars 2007.

[23]Raffournier B. (1990), « La théorie positive de la comptabilité : une revue de la littérature », Economies et Sociétés (Série Sciences de Gestion), Vol N ${ }^{\circ} 16$, pp 137-166.

[24]Roberts R.W., (1992), «Determinants of corporate social responsibility disclosure: an application of stakeholder theory», Accounting, Organizations and Society Review, Vol N ${ }^{\circ} 17$, Issue 6, pp. 595-612.

[25]Ullmann A., (1985), «Data in search of a theory: a critical examination of the relationship among social performance, social disclosure and economic performance of U.S. firms», Academy of Management Review, Vol N 10, Issue 3, pp. 540-577.
[26]Wood J. (1991), «Corporate Social Performance Revisited», Academy of Management Review, vol. $16 \mathrm{n}^{\circ} 4$, pp. 691-718.

[27]Zakaria, I. (2011), « Voluntary disclosure and political sensitivity: The case of executive remuneration», Working Paper. Essex Business School. University of Essex.

[28]Zeghal D. and Ahmed S.A., (1990), «Comparison of social responsibility information. Disclosure media used by Canadians firms», Accounting, Auditing and Accountability Journal, vol. 3, $\mathrm{n}^{\circ} 1$ 